\title{
Can HIF-1 Alpha (Hypoxia- inducible factor-1 alpha) be a New Cardiac Hypoxia Marker in Acute Coronary Ischemia?
}

\author{
HIF-1 Alfa (Hypoxia- inducible factor-1 alpha) akut Koroner İskemide \\ Yeni Bir Kardiyak Hipoksi Belirteci Olabilir Mi?
}

\author{
(D) Feray Akbaş, (D) Hanife Usta Atmaca, (D) Mehmet Emin Pişkinpaşa
}

University of Health Sciences Turkey, İstanbul Training and Research Hospital, Clinic of Internal Medicine, İstanbul, Turkey

\section{Abstract}

Objective: Hypoxia- inducible factor-1 alpha (HIF-1 alpha) is a gene protein whose activation is a primary defensive mechanism against tissue hypoxia. It is the main regulator of cellular oxygen delivery and consumption. HIF-1 alpha activity is increased in tissue ischemia and this induces the angiogenic growth factor release that is needed for vascular remodeling and collateral formation, and contributes to improvement in cardiac functions. In this study, it was aimed to measure HIF-1 alpha levels in acute cardiac ischemia, to evaluate its relationship with inflammatory and biochemical parameters, and to investigate HIF-1 alpha as a possible cardiac hypoxia marker.

Method: First 31 patients who were admitted to coronary ICU with Acute Coronary syndrome (ACS) diagnosis in March 2018 were included in the study and 22 ( 14 female, 8 male) age-gender-matched healthy control group were included in the study. In both case (coronary ICU patient) and control groups), after 12-hour hunger, venous blood samples were taken to measure HIF-1 alpha, biochemical parameters [glucose, urea, creatinine, uric acid, aspartate aminotransferase (AST), alanine aminotransferase (ALT), gamma-glutamyl transferase (GGT)], hemoglobin, platelets, platelet parameters [mean platelet volume (MPV), procalcitonin (PCT), platelet distribution width (PDW)], inflammatory parameters [C-reactive protein (CRP), neutrophil/lymphocyte ratio] and homocysteine levels. Results were evaluated using SPSS 22.0 program.

Results: Thirty one patients in the case group and 22 patients in the control group, totally 53 patients, were included in the study. The mean

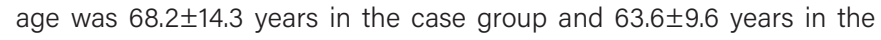
control group. Age and gender distribution, glucose, AST, ALT, PLT, MPV, PCT, PDW and homocysteine levels did not show any significant difference in the case and control groups $(p>0.05)$. Urea, creatinine, uric

\section{Öz}

\begin{abstract}
Amaç: Hipoxia- inducible factor-1 alfa (HIF-1 alfa) bir gen proteini olup, aktivasyonu, dokudaki hipoksiye karşı primer defansif mekanizmadır. Dokudaki oksijen dağıtımında ve kullanımında başlıca düzenleyicidir. Doku iskemisinde artan HIF-1 alfa aktivitesi vasküler remodeling ve kollateral oluşumu için gerekli anjiyogenik büyüme faktörü salınımını uyarır ve kardiyak fonksiyonların düzeltilmesine katkı sağlar. Bu çalışmada akut kardiyak iskemide HIF-1 alfa düzeyine bakılıp, biyokimyasal ve enflamatuvar parametreler ile olan ilişkisi değerlendirilerek, HIF-1 alfanın kardiyak hipoksi göstergesi olarak araştırılması amaçlanmıştır.
\end{abstract}

Yöntem: Çalışmaya koroner yoğun bakım ünitesine Mart 2018'de akut koroner sendrom tanısıyla yatırılan ilk 31 hastayla, yaş ve cinsiyet uyumlu 22 sağlıklı kontrol grubu alındı. Katılımcıların yaş ve cinsiyetleri kaydedildi. Yoğun bakıma alınan hastalardan yatış sonrası ilk 12 saat içinde ve kontrol grubundan 12 saat açlık sonrası alınan venöz kan örneklerinden HIF-1 alfa düzeyi, biyokimyasal parametreler [glukoz, üre, kreatinin, ürik asit, aspartat aminotransferaz (AST), alanin aminotransferaz (ALT), gama-glutamil transferaz (GGT], hemoglobin, trombositler, trombosit parametreleri [ortalama trombosit hacmi (MPV), prokalsitonin (PCT), trombosit dağılım genişliği (PDW)], enflamatuvar parametreler [C-reaktif protein (CRP), nötrofil/lenfosit oranı) ve homosistein bakıldı. Olgu ve kontrol gruplarının her ikisinde HIF-1 alfa düzeyi ve diğer araştırma parametreleri arasındaki ilişki SPSS 22.0 analiz programı ile değerlendirildi.

Bulgular: Çalışmaya 15 kadın, 16 erkek olmak üzere toplam 31 akut koroner sendrom tanılı hasta ile 14 kadın, 8 erkek olmak üzere toplam 22 sağlıkı kontrol grubu alındı. Yaş ortalaması olgu grubunda $68,2 \pm 14,3$ yıl ve kontrol grubunda $63,6 \pm 9,6 \mathrm{yll}$ idi. Olgu ve kontrol grubunda hastaların yaşları ve cinsiyet dağılımı anlamlı $(p>0,05)$ farklılık göstermedi. Olgu ve kontrol grubunda AKŞ değeri, AST değeri, ALT değeri, PLT değeri, MPV

Address for Correspondence: Feray Akbaş, University of Health Sciences Turkey, İstanbul Training and Research Hospital, Clinic of Internal Medicine, İstanbul, Turkey

E-mail: atlibatur@yahoo.com ORCID: orcid.org/0000-0001-5091-9160 Received: 13.10.2020 Accepted: 19.04.2021

Cite this article as: Akbaş F, Usta Atmaca H, Pişkinpaşa ME. Can HIF-1 Alpha (Hypoxia- inducible factor-1 alpha) be a New Cardiac Hypoxia Marker in Acute Coronary Ischemia? Bagcilar Med Bull 2021;6(2):168-173

(๑) Copyright 2021 by the Health Sciences University Turkey, Bagcilar Training and Research Hospital Bagcilar Medical Bulletin published by Galenos Publishing House. 


\section{Abstract}

acid, GGT, CRP, hemoglobin, and N/L levels were significantly higher in the case group when compared to the control group $(p<0.05)$. Although HIF-1 alpha level was higher in the case group when compared to the control group, it was not statistically significant.

Conclusion: There are studies showing the role of HIF-1 alpha in myocardial remodeling, angiogenesis and cardiac function improvement. In hypoxic conditions, increase in HIF-1 alpha improves tissue oxygenation. Same adaptive mechanism was not observed in our study. We think the reasons underlying this situation could be that in our patients, ischemia was localized but not generalized like in hypoxia, medical therapy was started immediately after admission (e.g.oxygen, nitrates, acetyl salicylic acid, heparin), the patients were normotensive under treatment, they did not have anemia, and they were given specific medications (e.g. ACE inhibitors, ARB) that could decrease oxidative distress.

New treatment modalities to protect the heart from ischemic damage will be available when our knowledge about cardiac functions at different oxygen levels and factors affecting them increases. Then, HIF-1 alpha might be re-evaluated as a potential cardiac hypoxia marker.

Keywords: Coronary ischemia, HIF-1 alpha, hypoxia

\section{Öz}

değeri, PCT değeri, PDW değeri ve homosistein değeri anlamlı $(p>0,05)$ farklılık göstermedi. Olgu grubunda üre değeri, kreatinin değeri, ürik asit değeri, GGT değeri, CRP değeri, Hgb değeri ve N/L değeri kontrol grubundan anlamlı $(p<0,05)$ olarak daha yüksek bulundu. Olgu grubunda HIF-1 alfa değeri, kontrol grubundan daha yüksek olmakla birlikte sonuç istatistiksel olarak anlamlı değildi.

Sonuç: HIF-1 alfanın artmış doku oksijenasyonu yoluyla kardiyak fonksiyonu düzeltmede etkisi olduğuna dair çok sayıda çalışma mevcuttur, ama aynı adaptif mekanizma çalışmamızda gözlenmemiştir. Sadece lokalize iskeminin varlığı, medikal tedavinin hemen başlanması, hipertansiyon veya anemi bulunmaması bu farklılık için açıklayıcı faktörler olabilir. Farklı oksijen konsantrasyonlarındaki kardiyak fonksiyonlar ve bunu etkileyen faktörler hakkında bilgimiz arttıkça, kalbi iskemik hasardan koruyacak yeni tedavi modalitelerinin de önü açılacaktır. O zaman HIF-1 alfa potansiyel bir kardiyak hipoksi belirteci olarak yeniden değerlendirilebilir.

Anahtar kelimeler: HIF-1 alfa, hipoksi, koroner iskemi

\section{Introduction}

Hypoxia- inducible factor-1 alpha (HIF-1 alpha) is a gene protein whose activation is a primary defensive mechanism against tissue hypoxia. It is the main regulator of cellular oxygen delivery and consumption. HIF-1 alpha activity is increased in tissue ischemia and this induces the angiogenic growth factor release that is needed for vascular remodeling and collateral formation and contributes to improvement in cardiac functions (1-5).

HIF pathway has a major role in most aspects of cardiovascular development and control. The principle of therapeutic modulation of HIF pathway has two components: Its pharmacological activation can enhance protective responses during cardiac ischemia or if it is applied prior to the cardiac event, it can moderate ischemic injury by preconditioning the tissue and protecting it from the distress $(6,7)$. Thus, HIF-1 alpha is suggested as a potential novel diagnostic and therapeutic tool in cardiac events (8).

In this study, it was aimed to measure HIF-1 alpha levels in acute cardiac ischemia, to evaluate its relationship with inflammatory and biochemical parameters, and to investigate HIF-1 alpha as a potential cardiac hypoxia marker.

\section{Materials and Methods}

This study was designed as a prospective, case-control study. First 35 patients who were admitted to coronary
ICU with Acute Coronary syndrome (ACS) diagnosis in March 2018 were included in the study. For the case group, inclusion criteria were age of 18 years or older, diagnosis of ACS, admission to coronary intensive care unit after emergency room evaluation and exclusion criteria were the presence of active malignancy or malignancy history and transfer from another hospital or ward. Four patients with active malignancy/malignancy history were excluded. In the same month, age-gender-matched 22 patients were randomly chosen from the internal medicine out-patient clinic as the healthy control group. For the control group, inclusion criteria were age of 18 years or older, age-gender match with the case group, internal medicine visit with any reason other than chronic diseases and exclusion criterion was the presence of any chronic disease history. Demographic features of both groups and accompanying diseases of the case group were recorded.

In the case group, the day after the admission, and in the control group, the day after outpatient clinic visit, venous blood samples were taken from antecubital vein after 12-hour hunger. All blood work was finished within 24 hours after the ACS diagnosis in the case group. HIF-1 alpha, biochemical parameters [glucose, urea, creatinine, uric acid, aspartate aminotransferase (AST), alanine aminotransferase (ALT), gamma-glutamyl transferase (GGT)], haemoglobin, platelets, platelet parameters [mean platelet volume (MPV), procalcitonin (PCT), platelet distribution width $(\mathrm{PDW})]$, inflammatory parameters 
[C-reactive protein (CRP), neutrophil/lymphocyte ratio] and homocysteine levels were measured. Synergy HT device was used to measure HIF-1 alpha level with ELISA method and Beckman Coulter AU 2700 plus (Beckman Coulter, Inc., Fullerton, USA) autoanalyzer was used to measure other parameters with spectrophotometric method. Results were evaluated using SPSS 22.0 program.

The study was conducted according to the Helsinki 1964 Declaration. Informed consent was obtained from all patients. Ethical approval was obtained from University of Health Sciences Turkey, İstanbul Training and Research Hospital Ethical Committee (1875/14.06.2019).

\section{Statistical Analysis}

Statistical analysis was performed using SPSS 22.0 for Windows program. Three types of descriptive statistics were used: Measures of frequency (frequency, percentage), measures of central tendency (mean, median), and measures of dispersion or variation (standard deviation, minimum, maximum). A measure of frequency is used for the categorical data while others were used for quantitative data. Distribution of variables was tested with the Kolmogorov-Smirnov test. Quantitative independent data analysis was made with the Mann-Whitney U test and qualitative independent data analysis with the chisquare test. The statistical significance level was regarded as $\mathrm{p}<0.05$.

\section{Results}

Thirty one cases (15 female, 16 male) and 22 controls (14 female, 8 male), totally 53 patients, were included in the study. The mean age was $68.2 \pm 14.3$ years in the case group and $63.6 \pm 9.6$ years in the control group. In the case group, 3 patients (9.6\%) had no accompanying diseases, 3 patients $(9.6 \%)$ had only one accompanying disease, and 25 patients (80.6\%) had $2 \geq$ accompanying diseases. The most common accompanying diseases included diabetes mellitus ( $n=13,41.9 \%)$, hypertension ( $n=18,58 \%)$, chronic heart failure $(n=10,32.2 \%)$, chronic renal failure $(n=6,19 \%)$, ischemic heart disease $(n=14,45 \%)$, and atrial fibrillation $(\mathrm{n}=6,13 \%)$. Age and gender distribution did not show any significant difference in the case and control groups (p>0.05). Fasting blood glucose, AST, ALT, PLT, MPV, PCT, PDW and homocysteine levels did not show any significant difference in the case and control groups ( $p>0.05$ ) (Table 1).

Urea, creatinine, uric acid, GGT, CRP, Hb, and N/L levels were significantly higher in the case group when

\begin{tabular}{|c|c|c|c|c|c|c|}
\hline & & \multicolumn{2}{|l|}{ Case group } & \multicolumn{2}{|l|}{ Control group } & \multirow[t]{2}{*}{$\mathbf{p}$} \\
\hline & & Mean \pm SD/n-\% & Median & Mean \pm SD/n-\% & Median & \\
\hline Age & & $68.2 \pm 14.3$ & 70.0 & $63.6 \pm 9.6$ & 68.0 & $0.102^{\mathrm{m}}$ \\
\hline \multirow[t]{2}{*}{ Gender } & Female & $15 \pm 48.4 \%$ & - & $14 \pm 63.6 \%$ & - & $0.272^{x^{2}}$ \\
\hline & Male & $16 \pm 51.6 \%$ & - & $8 \pm 36.4 \%$ & - & \\
\hline HIF-1 A & & $3.0 \pm 3.0$ & 1.9 & $2.0 \pm 1.8$ & 1.4 & $0.470^{m}$ \\
\hline FBG & & $152.8 \pm 77.8$ & 144.0 & $104.5 \pm 16.8$ & 104.0 & $0.093^{m}$ \\
\hline Urea & & $63.6 \pm 36.1$ & 49.0 & $33.4 \pm 8.5$ & 34.5 & $0.003^{m}$ \\
\hline Creatinine & & $1.22 \pm 0.54$ & 1.06 & $0.75 \pm 0.14$ & 0.72 & $0.000^{m}$ \\
\hline Uric acid & & $8.3 \pm 2.7$ & 7.9 & $4.8 \pm 1.3$ & 4.5 & $0.000^{m}$ \\
\hline AST & & $39.0 \pm 51.4$ & 23.0 & $25.4 \pm 16.2$ & 21.0 & $0.671^{\mathrm{m}}$ \\
\hline ALT & & $21.5 \pm 18.3$ & 17.0 & $22.6 \pm 10.9$ & 21.5 & $0.282^{m}$ \\
\hline GGT & & $51.4 \pm 50.0$ & 33.5 & $25.5 \pm 12.0$ & 22.0 & $0.047^{m}$ \\
\hline CRP & & $4.8 \pm 5.2$ & 3.2 & $0.2 \pm 0.3$ & 0.2 & $0.000^{m}$ \\
\hline Hgb & & $11.8 \pm 1.9$ & 11.9 & $13.6 \pm 1.6$ & 13.7 & $0.002^{m}$ \\
\hline$N / L$ & & $5.5 \pm 4.3$ & 4.2 & $1.6 \pm 0.4$ & 1.4 & $0.000^{m}$ \\
\hline PIt & & $231.1 \pm 65.7$ & 230.0 & $252.2 \pm 57.3$ & 254.0 & $0.236^{\mathrm{m}}$ \\
\hline MPV & & $10.5 \pm 1.2$ & 10.3 & $10.7 \pm 0.9$ & 10.7 & $0.541^{\mathrm{m}}$ \\
\hline PCT & & $0.24 \pm 0.06$ & 0.24 & $0.27 \pm 0.06$ & 0.27 & $0.117^{\mathrm{m}}$ \\
\hline PDW & & $15.5 \pm 16.3$ & 12.4 & $13.2 \pm 1.8$ & 13.0 & $0.296^{m}$ \\
\hline Homocysteine & & $17.4 \pm 7.0$ & 15.3 & $15.9 \pm 3.8$ & 14.6 & $0.704^{\mathrm{m}}$ \\
\hline
\end{tabular}

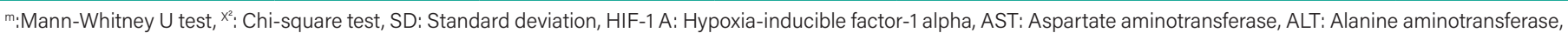
GGT: Gamma-glutamyl transferase, CRP: C-reactive protein, MPV: Mean platelet volume, PCT: Procalcitonin, PDW: Platelet distribution width 
compared to the control group ( $\mathrm{p}<0.05)$. Although HIF-1 alpha level was higher in the case group when compared to the control group, it was not statistically significant (Table 1).

\section{Discussion}

Cardiovascular diseases are the first main cause of mortality worldwide. 17.9 million people lose their lives from cardiovascular diseases each year, which is estimated to be $31 \%$ of all deaths (9). Coronary artery disease is a major part of this group of diseases. It is shown that ischemic heart disease affects around 126 million people worldwide, which is almost $1.72 \%$ of the world's population. $70 \%$ of individuals who are at-risk for ischemic heart disease have multiple cardiac risk factors and only $2-7 \%$ of the general population have no cardiac risk factors (10). Our study population consisted of ACS patients as a sample of this important global problem.

Despite impressive new developments in preventing and treating cardiovascular diseases, disease mortality did not change or decrease in most parts of the world (11). Thus, new approaches to detect cardiac disease risk factors/ presence with simple methods are needed urgently. HIF1 alpha seems to be a promising candidate to achieve this goal.

HIF-1 is a known transcriptional activator. It is oxygensensitive and it has a specific effect on several homeostatic responses in the presence of hypoxia $(12,13)$. It activates the transcription of several multiple hypoxia-inducible genes' transcription. Vascular endothelial growth factor, lactate dehydrogenase A, erythropoietin, main glycolytic enzymes, inducible nitric oxide synthase and heme oxygenase-1 are examples of those genes which are important components of cell survival, vascularization, adaptation, tissue homeostasis, anaerobic metabolism, cytokine production and immune reaction. Also, HIF1 has a key role in physiological system development in both fetal and postnatal lives. It is also a critical mediator of cardiovascular diseases, lung diseases, kidney diseases, and cancer $(13,14)$.

HIF-1 consists of alpha and beta subunits. The alpha subunit is distinctive to HIF-1 but beta subunit can combine with other bHLH-PAS proteins to form a dimer. HIF-1 alpha protein levels are increased in the presence of anemia or hypoxia (13). Nitric oxide inhibits hypoxia-induced HIF1 alpha expression (15). Because of its relationship with hypoxia, HIF-1 alpha is searched as a possible biomarker in different diseases (16-19) and we searched it with the same purpose in ACS patients.

HIF-1 alpha controls $\mathrm{O}_{2}$ delivery and utilization to regulate $\mathrm{O}_{2}$ homeostasis. When arterial stenosis causes ischemia or tissue hypoxia, HIF-1 activity is induced. This is needed to produce angiogenic growth factors and to trigger vascular remodeling. Consequently, blood flow in collateral vessels is increased. In people with advanced age or chronic diseases, this response of HIF-1 alpha is impaired. Ischemic preconditioning is described as repeated short episodes of ischemia and reperfusion to protect the myocardium against injury caused by prolonged ischemia. HIF-1 alpha also has a role in this heart protective action. Increased cardiac adenosine levels are efficient for cardioprotection and HIF-1 is involved in adenosine production, too. Also, it reduces reactive oxygen species to contribute to metabolic reprogramming for preventing myocardial injury caused by prolonged ischemia-reperfusion (20).

Same adaptive mechanism was not observed in our study. Although HIF-1 alpha level was increased in the case group when compared to the control group, the difference was not statistically significant. We think there might be several reasons underlying this situation. First of all, ischemia was localized but not generalized in our patients, medical therapy was started immediately after admission (e.g. oxygen, nitrates, acetyl salicylic acid, heparin), the patients were normotensive under treatment, they did not have anemia, and they were given specific medications (e.g. ACE inhibitors, ARB) that could decrease oxidative distress. Also, renal function tests, inflammatory markers and uric acid levels were higher in the case group. This was attributed to accompanying diseases and acute inflammation related to acute coronary ischemia in the case group.

There have been several studies presenting how HIF1 alpha favors in acute cardiac ischemia. Ong et al. (21) showed that HIF-1 alpha reduced cardiac ischemiareperfusion injury in mice and murine. Ockaili et al. (22) also pointed out that HIF-1 had a newly presented anti-inflammatory role in ischemia-reperfusion injury. Similarly, Kido et al. (23) found that HIF 1-alpha reduced infarction and attenuated further cardiac damage after myocardial infarction in their mouse study. Several studies found similar results. Thus, HIF-1 alpha was suggested as a therapeutic target for heart diseases that could be used in the near future (24). 


\section{Conclusion}

In hypoxic conditions, increase in HIF-1 alpha favors to tissue oxygenation. Although the same adaptive mechanism could not be mimicked in our study, there are several studies demonstrating the role of HIF-1 alpha in myocardial remodeling, angiogenesis and cardiac function improvement. New treatment modalities to protect the heart from ischemic damage will be available when our knowledge about cardiac functions at different oxygen levels and factors affecting them increases. Then, HIF-1 alpha might be re-evaluated as a potential cardiac hypoxia marker and it can be used in a broader prospect both for the diagnosis and the treatment part of ischemic heart diseases.

The study group included 31 people and the control group included 22 people. More accurate results could have been obtained if the number of both groups had been equal and both groups had had more patients. However, unfortunately, limited HIF test kit availability did not allow us to increase the numbers.

\section{Ethics}

Ethics Committee Approval: The study was conducted according to the Helsinki 1964 Declaration. Ethical approval was obtained from University of Health Sciences Turkey, İstanbul Training and Research Hospital Ethical Committee (1875/14.06.2019).

Informed Consent: Informed consent was obtained from all patients.

Peer-review: Externally and internally peer-reviewed.

\section{Authorship Contributions}

Concept: F.A., H.U.A., Design: F.A., H.U.A., M.E.P., Data Collection or Processing: F.A., H.U.A., Literature Search: F.A., M.E.P., Analysis or Interpretation: F.A., H.U.A., M.E.P., Writing: F.A., H.U.A., M.E.P.

Conflict of Interest: No conflict of interest was declared by the authors.

Financial Disclosure: The authors declared that this study has received no financial support.

\section{References}

1. Wenger RH, Gassmann M. Oxygen(es) and the hypoxia-inducible factor-1. Biol Chem 1997;378(7):609-616.

2. Aljakna A, Fracasso T, Sabatasso S. Molecular tissue changes in early myocardial ischemia: from pathophysiology to the identification of new diagnostic markers. Int J Legal Med 2018;132(2):425-438.
3. Tanaka T, Eckardt KU. HIF activation against CVD in CKD: novel treatment opportunities. Semin Nephrol 2018;38(3):267-276.

4. Du Y, Ge Y, Xu Z, Aa N, Gu X, Meng H, et al. Hypoxia-inducible factor 1 alpha (HIF-1 $\alpha$ )/vascular endothelial growth factor (VEGF) pathway participates in angiogenesis of myocardial infarction in muscone-treated mice: preliminary study. Med Sci Monit 2018;24:8870-8877.

5. Li M, Cui Y, He W, Deng X, Wang Y, Cai M, et al. Effects of triplemutated hypoxia-inducible factor- $1 \alpha$ on angiogenesis and cardiac function improvement in rats with myocardial infarction. Cell Physiol Biochem 2018;50(6):2329-2340.

6. Bishop T, Ratcliffe PJ. HIF hydroxylase pathways in cardiovascular physiology and medicine. Circ Res 2015;117(1):65-79.

7. Shohet RV, Garcia JA. Keeping the engine primed: HIF factors as key regulators of cardiac metabolism and angiogenesis during ischemia. J Mol Med 2007;85(12):1309-1315.

8. Liu M, Galli G, Wang Y, Fan Q, Wang Z, Wang X, et al. Novel therapeutic targets for hypoxia-related cardiovascular diseases: the role of HIF-1. Front Physiol 2020;11:774.

9. WHO Home/Helath topics/ Cardiovascular disesases. Last Accessed Date: 24.09.2020. Available from: https://www.who.int/ health-topics/cardiovascular-diseases\#tab=tab_1

10. Khan MA, Hashim MJ, Mustafa H, Baniyas MY, Al Suwaidi SKBM, AlKatheeri R, et al. Global epidemiology of ischemic heart disease: results from the global burden of disease study. Cureus 2020;12(7):e9349. doi: 10.7759/cureus.9349.

11. Roth GA, Johnson C, Abajobir A, Abd-Allah F, Abera SF, Abyu G, et al. Global, regional, and national burden of cardiovascular diseases for 10 causes, 1990 to 2015. J Am Coll Cardiol 2017;70(1):1-25.

12. Ke Q, Costa M. Hypoxia-inducible factor-1 (HIF-1). Mol Pharmacol 2006;70(5):1469-1480.

13. Semenza GL, Agani F, Booth G, Forsythe J, Iyer N, Jiang BH, et al. Structural and functional analysis of hypoxia-inducible factor 1. Kidney Int 1997;51(2):553-555.

14. Adams JM, Difazio LT, Rolandelli RH, Luján JJ, Haskó G, Csóka B, et al. HIF-1: a key mediator in hypoxia. Acta Physiol Hung 2009;96(1):19-28.

15. Semenza GL. HIF-1 and mechanisms of hypoxia sensing. Curr Opin Cell Biol 2001;13(2):167-171.

16. Kerget B, Afşin DE, Aksakal A, Aksakal A, Aşkin S, Araz Ö. Could HIF-1? be a novel biomarker for the clinical course and treatment of pulmonary embolism? Turk J Med Sci 2020;50(4):963-968.

17. Shintani K, Matsumine A, Kusuzaki K, Matsubara T, Satonaka H, Wakabayashi T, et al. Expression of hypoxia-inducible factor (HIF)-1alpha as a biomarker of outcome in soft-tissue sarcomas. Virchows Arch 2006;449(6):673-681.

18. Mashiko R, Takano S, Ishikawa E, Yamamoto T, Nakai K, Matsumura A. Hypoxia-inducible factor $1 \alpha$ expression is a prognostic biomarker in patients with astrocytic tumors associated with necrosis on MR image. J Neurooncol 2011;102(1):43-50.

19. Kumar M, Sharma K, Maruti M, Bhoi S, Baitha U, Kumar M. Hypoxia-inducible factor 1: A biomarker for Acute Respiratory Distress Syndrome? Indian J Immunol Respir Med 2016;1 (1);1-2.

20. Semenza GL. Hypoxia-inducible factor 1 and cardiovascular disease. Annu Rev Physiol 2014;76:39-56. 
21. Ong SG, Lee WH, Theodorou L, Kodo K, Lim SY, Shukla DH, et al. HIF-1 reduces ischaemia-reperfusion injury in the heart by targeting the mitochondrial permeability transition pore. Cardiovasc Res 2014;104(1):24-36.

22. Ockaili R, Natarajan R, Salloum F, Fisher BJ, Jones D, Fowler AA, et al. HIF-1 activation attenuates post-ischemic myocardial injury: role for heme oxygenase-1 in modulating microvascular chemokine generation. Am J Physiol Heart Circ Physiol 2005;289(2):H542-H548. doi: 10.1152/ajpheart.00089.2005
23. Kido M, Du L, Sullivan CC, Li X, Deutsch R, Jamieson SW, et al. Hypoxia-inducible factor 1-alpha reduces infarction and attenuates progression of cardiac dysfunction after myocardial infarction in the mouse. J Am Coll Cardiol 2005;46(11):2116-2124.

24. Townley-Tilson WHD, Pi X, Xie L. The role of oxygen sensors, hydroxylases, and HIF in cardiac function and disease. Oxid Med Cell Longev 2015;2015:676893. 